\title{
Preparation, Characterization and Antimicrobial Activity Study of Some Transition Metal Complexes of 4- Flourophenyl -4-Nitrobenzylidene
}

\author{
Zeyan Abdullah Ali* Ameera Hassan Hamed** \\ Rafah Khalid Ahmed **
}

Date of acceptance 9/2/2010

\begin{abstract}
:
A new Schiff base of 4- flourophenyl-4- nitrobenzyliden (L), was prepared and used to prepare a number of metal complexes with $\mathrm{Cr}$ (III), $\mathrm{Fe}$ (III), $\mathrm{Co}$ (II) ,Ni (II) and $\mathrm{Cu}$ (II). These complexes were isolated and characterized by (FITR),UV-Vis spectroscopy and flame atomic absorption techniques in addition to magnetic susceptibility, and conductivity measurements. The study of the nature of the complexes formed in ethanol was done following the molar ratio method gave results, agreed with those obtained from isolated solid state studies. The antibacterial activity for the ligand and its metal complexes were examined against two selected microorganisms, Pseudomonas aeruginosa and Staphylococcus aureus. The results indicated that the complexes show the enhanced activity in comparison to the free ligand; these were attributed to the synergetic effect between the metal ion and the ligand in addition to the difference in the structural varieties.
\end{abstract}

\section{Key words: Synthesis; 4-Flourophnyl-4-nitrobenzylidene; Metal complexes.}

\section{Introduction:}

Schiff base offer a versa file and flexible series of ligands capable to bind with various metal ions to give complexes with suitable properties for theoretical and practical applications (1). A large number of imine complexes have been structurally characterized and extensively investigated (1).Many transition elements have been extensively investigated with regard to their potential quality as anticancer agent (2),and they are found to be useful in catalysis, in medicine as antibiotics, anti-inflammatory agents and in industry as anticorrosion (37).However, several observations suggest that also other metals containing compounds might be suitable for the development of new chemotherapeutics like La(III)salts have been reported to exert moderate antiproliforative effects in vitro(8)and in vivo (9).From this point we found it is interesting to isolate and study the biological activity of some new $\mathrm{Cr}(\mathrm{III}), \mathrm{Fe}(\mathrm{III}), \mathrm{Co}(\mathrm{II}), \mathrm{Ni}$ (II) and $\mathrm{Cu}(\mathrm{II})$ imines complexes .

\section{Materials and methods:}

All chemicals used were of the analytical grade (Analar) and of highest purity available. The metal analyses of the separated solid chelates for metal content were performed by using Shimadzu Atomic Absorption Spectrophotometer Flame (680-AA), Electronic spectra of the complexes were recorded on a Shimadzu UV 160 Spectrophotometer. FTIR spectra

*University of Salahaddin-Hawler,Eduction-Science - Iraq

**University of Baghdad,College of Science for Women - Iraq 
of the samples were recorded on a Shimadzu IR Pestige - 21 Spectrophotometer as CSI discs. Magnetic Susceptibility measurements of the complexes in the solid state were determined using Burker BM6

Instrumentation at room temperature. Molar conductance of the complexes were measured in DMF as solvent at room temperature using a (HANNA EC 214) conductivity type.

Preparation of 4-flourophenyl -4nitrobenzylidene $(\mathrm{L})$ :

An absolute ethanolic solution $(30 \mathrm{ml})$ of 4-flourophenyl -4-nitrobenzylidene (0.01mole) was refluxed with 4-para nitro benzaldehyde $(0.01 \mathrm{~mole})$ for about $10 \mathrm{hrs}$. The formed solid produced cooled and was separated by filtration, purified by crystallization from ethanol, then washed with diethyl ether and dried in vacuum desiccator over anhydrous calcium chloride. The yellow product was collected and 92\% Structural of the proposed ligand is shown below equation yield.

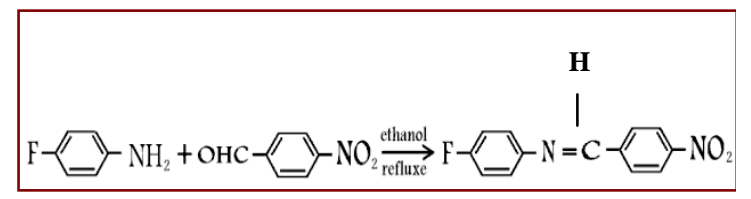

\section{Preparation of complexes}

Imine complexes under investigation were synthesized as follows; the ligand was dissolved in $20 \mathrm{ml}$ ethanol and added to metal salt in ethaolic solution. The reaction molar ratio was (1:2) metal: ligand for all prepared complexes except chromium complex (1:3). The mixture refluxed for 2 hrs. The products were filtered after cooling and washed several times with ethanol and dried over anhydrous $\mathrm{CaCl}_{2}$.

\section{Study of complex formation in solution}

Complexes of imine with metal ions were studied in solution using ethanol as solvent, in order to determine the concentration of metal to ligand ratio in the complex following molar ratio method (10). A series of solutions were prepared having a constant concentration $10^{-4} \mathrm{M}$ of each metal ion and the ligand.The [M: L] ratio was determined from the relationship between the absorption of the absorbed light and the mole ratio of the $[\mathrm{M} / \mathrm{L}]$ at $\lambda_{\max }$.The results of complexes formation in solution were listed in Table (1) and Figure (1).

\section{Antimicrobial activity}

Disc diffusion method was used for screening the ligand and its metal complexes. Nutrient agar plates were inoculated with $0.1 \mathrm{ml}$ of an appropriate dilution of the tested culture. Samples $(1 \mathrm{~cm}$ diameter) were suspended in (100) $\mathrm{ml}$ of sterile distilled water. About (20) $\mathrm{ml}$ of each suspension was added a filter paper disc $(6 \mathrm{~mm}$ diameter), which were placed on surface of previously inculcate plates. The plates were incubated at the appropriate temperature for $24 \mathrm{hrs}$.

\section{Results and Discussion: \\ A. Chemistry}

Physical properties, metal analyses, magnetic susceptibility and conductivity data of the complexes are given in Table (1to3). The analytical data of the complexes correspond of the general formula can be deduced as $\left[\mathrm{ML}_{\mathrm{n}} \mathrm{CL}_{\mathrm{m}} \quad\right] . \mathrm{H}_{2} \mathrm{O}$, where $\quad, \mathrm{M}=\mathrm{Cr}$ (III) , $\mathrm{Co}(\mathrm{II})$ and $\mathrm{n}, \mathrm{m}=2,3$ respectively andML $\left.2\left(\mathrm{NO}_{3}\right)_{\mathrm{n}}\left(\mathrm{H}_{2} \mathrm{O}\right)_{\mathrm{m}}\right]$.XEtOH, where , $\mathrm{M}=\mathrm{Fe}$ (III), $\mathrm{Ni}(\mathrm{II})$ and $\mathrm{Cu}(\mathrm{II}), \mathrm{n}=1,0,2$ and $\mathrm{X}=1.5,2,4$ respectively .

The IR spectra of the complexes were compared with that of the free ligand to determine the changes that might have taken place during the complexation. The band at $1631 \mathrm{~cm}^{-1}$ is characteristic of the azomethine 
nitrogen atom present in the free ligand. The lowering in this frequency region (1622-1600) $\mathrm{cm}^{-1}$ observed in all complexes indicates the involvement of the azomethine nitrogen atom in coordination $[11,12]$. Moreover, new bands appeared in all compounds (459-535) $\mathrm{cm}^{-1}$ regions which assigned to $v(\mathrm{M}-\mathrm{N})$ vibration (12). New bands appeared in chromium and cobalte complexes $(266,220) \mathrm{cm}^{-1}$ regions which assigned to $v(\mathrm{M}-\mathrm{Cl})$ vibration indicating the formation of metal chloride coordinated bond $(12,13)$. Appearance of the nitrate band groups for the copper, iron, and nickel complexes, showing the linkage of this group through one oxygen atom (12).A broad band around (3425-3250) $\mathrm{cm}^{-1}$ indicating the presence of coordinated or lattic water or ethanol in all complexes.

The electronic spectrum of the chromium complex showed bands in the region (11.695, 22.222 and 27.700) $\mathrm{cm}^{-1}$ corresponding to the transition ${ }^{4} \mathrm{~A}_{2 \mathrm{~g}} \longrightarrow{ }^{4} \mathrm{~T}_{2 \mathrm{~g},}{ }^{4} \mathrm{~T}_{2 \mathrm{~g}} \longrightarrow{ }^{4} \mathrm{~T}_{1 \mathrm{~g}(\mathrm{~F})}$

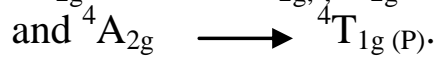

Respectively. The results are in good agreement with those reported for an octahedral geometry around $\mathrm{Cr}$ (III) ion $(14,15)$. The magnetic moment is (3.42BM)with three electrons in an octahedral configuration. Conductivity measurements in DMF showed that the chromium complex was to be non ionic.

The magnetic measurement showed that the iron ion in its brown complex to be high spin paramagnetic (5.23BM ), of $\mathrm{d}^{5}$ configuration. This suggestion was supported by the number of maxima observed in the electronic spectrum of this complex, which show three bands at $(10,288,16,129$ and 21,321$) \mathrm{cm}^{-1}$, that may be assigned to the transition ${ }^{6} \mathrm{~A}_{1 \mathrm{~g}} \longrightarrow{ }^{4} \mathrm{~T}_{1 \mathrm{~g}(\mathrm{G})}, \quad{ }^{6} \mathrm{~A}_{! \mathrm{g}} \longrightarrow{ }^{4} \mathrm{~T}_{2 \mathrm{~g}(\mathrm{G})}$ and ${ }^{6} \mathrm{~A}_{1 \mathrm{~g}} \longrightarrow{ }^{4} \mathrm{~A}_{1 \mathrm{~g}}+{ }^{4} \mathrm{E}_{(\mathrm{g})}$ respectively.
These data compare with those reported for an octahedral geometry around Fe (III) ion $(14,16)$.The conductivity measurements showed the complex to be non-electrolyte.

The Yellowish-green cobalt (II) complex with ligand showed a magnetic moment of (4.7BM), which indicates a high-spin type complex. Electronic spectrum in ethanol solution exhibited a split band in the range of (16.000-14.000) $\mathrm{cm}^{-1}$, this split band is a typical tetrahedral spectra type and this band can be assigned as a

${ }^{4} \mathrm{~A}_{2} \longrightarrow \mathrm{T}_{1(\mathrm{p})}$, in addition there is a band at $3430 \mathrm{~cm}^{-1}$ belong to be from infrared spectrum can be assigned to ${ }^{4} \mathrm{~A}_{2} \longrightarrow{ }^{4} \mathrm{~T}_{2(\mathrm{~F})}$ transition $(17,18)$. The molar conductance showed that the complex is non-electrolyte.

The Ni(II) complex shows two bands in the regions $(20,833$ and $18,181) \mathrm{cm}^{-1}$ typical of 4-coordinate square planar geometry and can be assigned to ${ }^{1} \mathrm{~A}_{1 \mathrm{~g}} \longrightarrow{ }^{1} \mathrm{~B}_{1 \mathrm{~g}} \quad$ and ${ }^{1} \mathrm{~A}_{1 \mathrm{~g}} \longrightarrow{ }^{1} \mathrm{~B}_{2 \mathrm{~g}}$ transitions $(15,19,20)$. Also the absence of any band below $10.000 \mathrm{~cm}^{-1}$ eliminated the possibility of a tetrahedral environment in this complex. The conductivity behavior in DMF shows the complex to be non ionic. The magnetic measurement data is $(0.98 \mathrm{BM})$, which shows this complex to be diamagnetic.

The electronic spectrum of green copper (II) complex, showed one a broad band at $12.345 \mathrm{~cm}^{-1}$ which assigned to ${ }^{2} \mathrm{E}_{\mathrm{g}} \longrightarrow{ }^{2} \mathrm{~T}_{2 \mathrm{~g}}$ transition, which conform the octahedral geometry. The value of magnetic moment at room temperature $(1.8 \mathrm{BM}$ )is due to one unpaired of $3 \mathrm{~d}^{9}$ electronic configuration in an octahedral complex of $\mathrm{Cu}$ (II) ion . The conductivity measurement of the copper complex showed it to be non ionic.

In solution study, the molar ratio method was carried out to determine the ratio of $M$ : $L$. The results of the 
complexes in ethanol can be shown in figure (2) suggests that the metal to ligand ratio was (1:3) for chromium complex and (1:2) for the other complexes, which are monomeric nature for all compouns and then were comparable to these obtained from isolated solid state. Table (1)
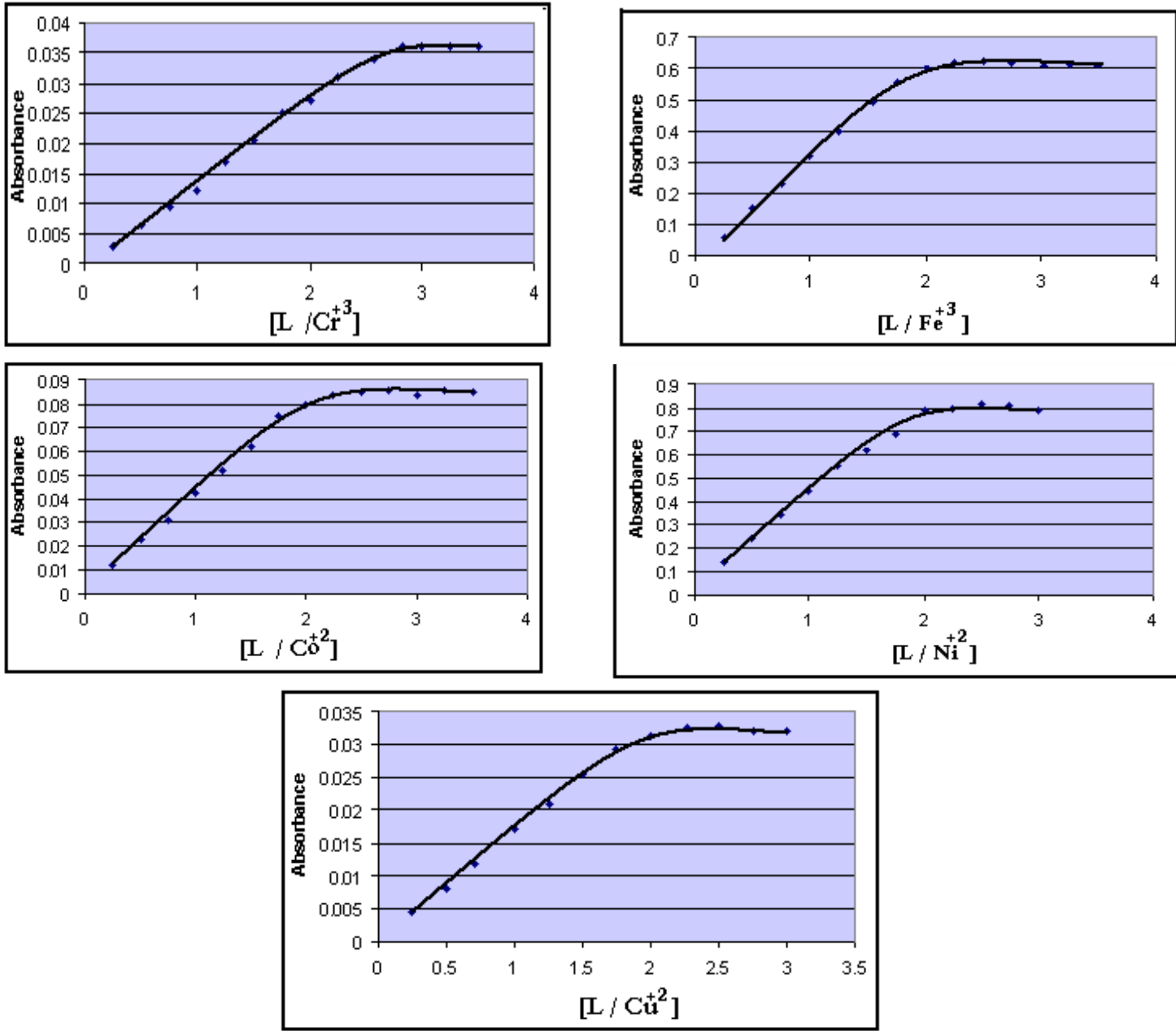

Fig (1): Molar ratio plot of all complexes prepared

The proposed coordination of the Schiff base complexes can be suggested as follows:

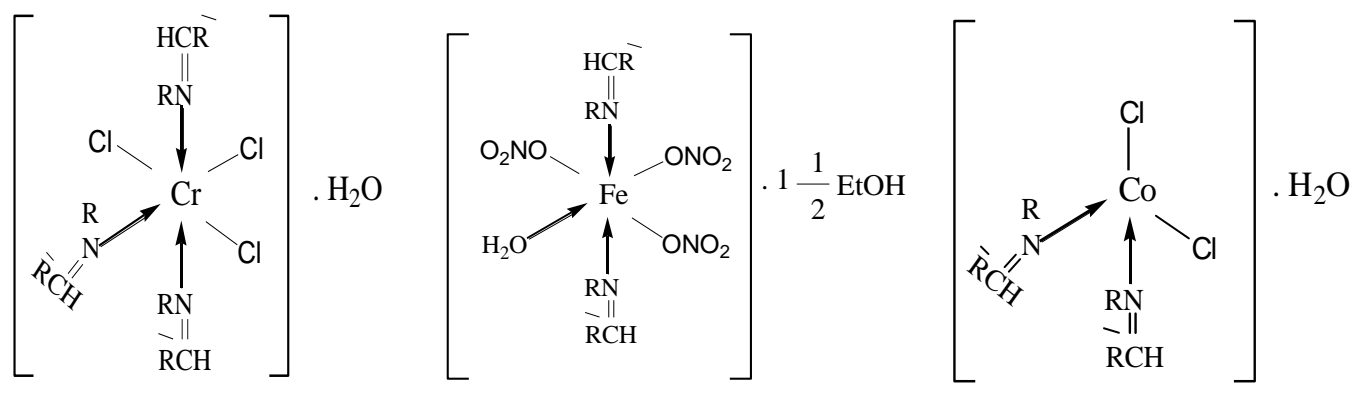




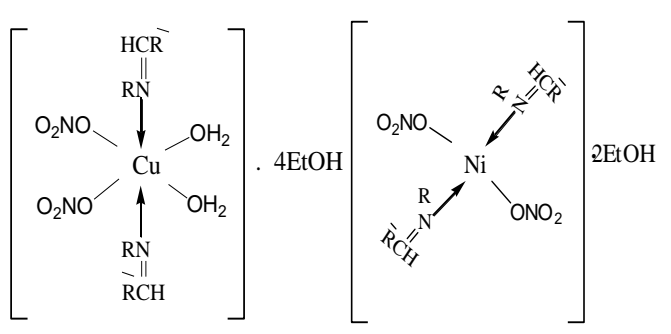

Where $\quad \mathrm{R}=\mathrm{C}_{6} \mathrm{H}_{4} \mathrm{~F}$

$$
\overleftarrow{\mathrm{R}}=\mathrm{C}_{6} \mathrm{H}_{4} \mathrm{NO}_{2}
$$

\section{Biological Activity}

The results indicate that the complexes show more activity and the ligand do not have any activity against all organisms under identical experimental conditions in low concentration and slightly active at higher concentration. The antimicrobial activity could be mainly due to the structure of these complexes and the oxidation state of the metal ions. These results would suggest that the chelation could facilitate the ability of the complex to cross the cell membrane (21). Coordination considerably reduces the polarity of the metal ion mainly because of partial sharing of its positive charge with the donor groups and possible electron delocalization over the whole coordination ligand. Such coordination could also enhance the lipophilic character of the central metal atom, which subsequently favors its permeation through the layer of the cell membranes (22).

Table (1): Physical properties of the ligand and it's metal complexes

\begin{tabular}{|c|c|c|c|c|c|c|}
\hline Compound & Color & M.PC & $\underset{\%}{\text { Yield }}$ & $\begin{array}{l}\text { Ratio } \\
\text { M:L }\end{array}$ & $\begin{array}{c}\text { Metal } \\
\text { content } \\
\text { Found (cal.) }\end{array}$ & Formula structure \\
\hline $\mathbf{L}$ & Yellow & $\begin{array}{l}190- \\
192\end{array}$ & 92 & - & - & $\mathrm{C}_{13} \mathrm{H}_{9} \mathrm{~N}_{2} \mathrm{O}_{2} \mathrm{~F}$ \\
\hline CrL & darck green & 110 & 62 & $1: 3$ & $6.44(5.91)$ & {$\left[\mathrm{Cr} \mathrm{L}_{3} \mathrm{Cl}_{3}\right] . \mathrm{H} 2 \mathrm{O}$} \\
\hline FeL & Dark brown & 298 & 75 & $1: 2$ & $7.51(6.90)$ & $\begin{array}{c}{\left[\mathrm{FeL}_{2}\left(\mathrm{NO}_{3}\right)_{3}\left(\mathrm{H}_{2} \mathrm{O}\right)\right] \cdot 1} \\
1 / 2 \mathrm{EtOH}\end{array}$ \\
\hline CoL & $\begin{array}{c}\text { Yellowish- } \\
\text { green }\end{array}$ & 243 & 60 & $1: 2$ & $10.22(9.57)$ & {$\left[\mathrm{CoL}_{2} \mathrm{Cl}_{2}\right] \cdot \mathrm{H}_{2} \mathrm{O}$} \\
\hline NiL & Orange & 136 & 80 & $1: 2$ & $8.02(7.56)$ & {$\left[\mathrm{NiL}_{2}\left(\mathrm{NO}_{3}\right)_{2}\right] .2 \mathrm{EtOH}$} \\
\hline $\mathrm{CuL}$ & green & 275 & 76 & $1: 2$ & $7.82(7.25)$ & {$\left[\mathrm{CuL}_{2}\left(\mathrm{NO}_{3}\right) 2\left(\mathrm{H}_{2} \mathrm{O}\right)_{2}\right] .4 \mathrm{EtOH}$} \\
\hline
\end{tabular}

d:decomposed point .

Table (2): Most diagnostic Infrared bands $\left(\mathrm{cm}^{-1}\right)$ of the compounds under investigation

\begin{tabular}{|c|c|c|c|c|c|c|}
\hline Compund. & $\mathrm{v}-\mathrm{OH}$ & $v-\mathrm{C}=\mathrm{N}$ & v M-O & vM-N & vM-Cl & $\mathrm{v}-\mathrm{ONO}_{2}$ \\
\hline $\mathbf{L}$ & - & 1631 & - & - & - & - \\
\hline CrL & 3284 & 1622 & - & 475 & 266 & - \\
\hline FeL & 3425 & 1610 & 450 & 530 & - & $\begin{array}{l}1000 \\
1305 \\
1410\end{array}$ \\
\hline CoL & 3367 & 1621 & - & 462 & 220 & - \\
\hline NiL & 3447 & 1621 & - & 535 & - & $\begin{array}{l}1010 \\
1315 \\
1405 \\
\end{array}$ \\
\hline CuL & 3484 & 1600 & 442 & 459 & - & $\begin{array}{l}1000 \\
1315 \\
1410\end{array}$ \\
\hline
\end{tabular}


Table (3): Electronic spectra, magnetic moment and conductivity measurements of the imine complexes under investigation

\begin{tabular}{|c|c|c|c|c|c|c|}
\hline Compound & $\begin{array}{l}\text { Bands } \\
\lambda(\mathbf{n m})\end{array}$ & $\begin{array}{l}\text { Bands } \\
v(\mathrm{~cm})^{-1}\end{array}$ & assignment & $\begin{array}{c}\mu \text { off } \\
\text { BM }\end{array}$ & $\mu \mathbf{s c m}^{-1}$ & $\begin{array}{l}\text { Geometry } \\
\text { Suggested }\end{array}$ \\
\hline CrL & $\begin{array}{l}855 \\
450 \\
367\end{array}$ & $\begin{array}{l}11.695 \\
22.222 \\
27.700\end{array}$ & 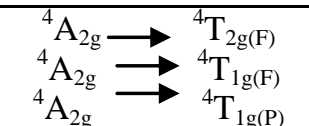 & 3.42 & 21 & octahedral \\
\hline FeL & $\begin{array}{l}972 \\
620 \\
469 \\
\end{array}$ & $\begin{array}{l}10.288 \\
16.129 \\
21.32 \\
\end{array}$ & $\begin{array}{l}{ }^{6} \mathrm{~A}_{1 \mathrm{~g}} \longrightarrow{ }^{4} \mathrm{~T}_{1 \mathrm{~g}(\mathrm{G})} \\
{ }^{6} \mathrm{~A}_{1 \mathrm{~g}} \longrightarrow{ }^{4} \mathrm{~T}_{2 \mathrm{~g}(\mathrm{G})} \\
{ }^{6} \mathrm{~A}_{1 \mathrm{~g}} \longrightarrow{ }^{4} \mathrm{~A}_{1 \mathrm{~g}}+{ }^{4} \mathrm{E}_{\mathrm{g}(\mathrm{G}}\end{array}$ & 5.23 & 28 & octahedral \\
\hline CoL & $(674+652)$ av. & $\begin{array}{c}3430 \\
15.086 \\
\end{array}$ & $\begin{aligned} &{ }^{4} \mathrm{~A}_{2} \longrightarrow{ }^{4} \mathrm{~T}_{2} \\
&{ }^{4} \mathrm{~A}_{2} \longrightarrow{ }^{4} \mathrm{~T}_{1(\mathrm{P})} \\
&\end{aligned}$ & 4.70 & 16 & tetrahedral \\
\hline NiL & $\begin{array}{l}550 \\
480 \\
\end{array}$ & $\begin{array}{l}18.181 \\
20.833 \\
\end{array}$ & $\begin{array}{l}{ }^{1} \mathrm{~A}_{1 \mathrm{~g}} \longrightarrow{ }^{1} \mathrm{~B}_{1 \mathrm{~g}} \\
{ }^{1} \mathrm{~A}_{1 \mathrm{~g}} \longrightarrow{ }^{1} \mathrm{~B}_{2 \mathrm{~g}} \\
\end{array}$ & 0.98 & 20 & square planer \\
\hline CuL & 810 & 12.345 & ${ }^{2} \mathrm{E}_{2 g} \longrightarrow{ }^{2} \mathrm{~T}_{2 g}$ & 1.8 & 19 & octahedral \\
\hline
\end{tabular}

$\mathrm{aV}=$ average

Table (4): Effect of the Schiff base and it's metal complexes on the Bacterial growth.

\begin{tabular}{|c|c|c|c|c|}
\hline \multirow{2}{*}{ compound } & \multicolumn{2}{|c|}{$\begin{array}{c}\text { (-)Pseudomonas } \\
\text { aeruginosa }\end{array}$} & \multicolumn{2}{c|}{$\begin{array}{c}\text { (+) Staphylococcus } \\
\text { aurens }\end{array}$} \\
\cline { 2 - 5 } & $\mathbf{5 m M}$ & $\mathbf{1 0 m M}$ & $\mathbf{5 m M}$ & $10 \mathrm{mM}$ \\
\hline L & - & + & - & + \\
\hline CrL & ++ & +++ & + & + \\
\hline FeL & - & - & + & ++ \\
\hline CoL & + & ++ & ++ & +++ \\
\hline NiL & ++ & +++ & - & - \\
\hline CuL & + & + & +++ & ++ \\
\hline
\end{tabular}

$(-)=(0-0.3) \mathrm{mm}$ inhibition $=$ inactive

$(+)=(0.3-0.9) \mathrm{mm}=$ slightly active

$(++)=(0.9-1.2) \mathrm{mm}=$ moderately active

$(+++)=1.2-1.6) \mathrm{mm}=$ active

\section{References}

1. Middleton, A.R., Mosters, A.F. and Wilkinson, G. 1979. Schiff Base Complexes of Rhenium (V), J. The Chemical Society.3 (issu): 542-546.

2 Petra, H., Michael, A.J., Wilfred, K., Stefan, W., Nkolai, G. K., Leonilla, E. 2006.Anticancer activity of the lanthanum compound [tris $(1,10-$ phenanthroline) lanthanum (III) trithocyanate, J. Biochemical Pharmacology. 71(4):426.

3. Liu, J., Wu, B., Zharg, B. and LiuTurk, Y. 2006. Syntheses and characterization of Metal
Complexes of $\mathrm{Cu}$ (II), Ni (II) $\mathrm{Zn}$ (II), Co(II) ,Mn (II) and Cd (II) with Treatment Schiff Base, J.Chem. 30: 41-48.

4. Boghaei, D .M. and Mohebi, S. 2002. Non -Symmetrical Tetradenate Vanadyle Schiff Base Complexes derived from 1, 2phenylene diamine and 1, 3Naphthalane diamine as Catalyst for the oxidation of Cyclohexene, Tertahedron .58(26): 5057-5366

5. Jin, V.X., Tan, S.I. and Ranford, J.D. 2005. Platinum (II) triammine antitumour complexes: strcurure activity relationship with guanosine 5-monmphosphate (5-GMP), J. Inorg.Chem. 358 (3): 677.

6. Budakoti, A., Abid, M. and Zam, A.A. 2006. Syntheses and antiamoebic activity of new $1-\mathrm{N}$ substituted thiocarbamoyl-3, 5diphenyl-2-pyrazoline derivatives and their Pd (II) complexes Eur.J. Med.Chem. 41(1): 63-70.

7. Mehta, N.K. and Agarusala, V.S. 1996.Aflourinated Schiff base compound (imine) as an inhibitor for corrosion and wear, Int. Corros. Cong.Proc. 13(319): 1.

8. Estacion, M. and Mordan, L.J.1993. Competence Induction by PDGF requie Sustained calcium influx by a Mechanism distinct from storage- 
Dependent calcium influx.cell calcium. 14: 439.

9. Le Dpold, J.L. and Anghileri. 1979. Effects of gallium and lanthanum on experimental tumor growth , Eur.J.Cancer. 15(12): 1459-1462.

10. Skooge, A.D. 1988. Fundamental of Analytical Chemistry. Ed.5th, New York.

11. Mahapatra, B.B. and Das, D.K. 1987. Mixed -ligand complexes of $\mathrm{Co}(\mathrm{II}), \mathrm{Cu}(\mathrm{II}), \quad \mathrm{Zn}(\mathrm{II}) \quad \mathrm{Cd}(\mathrm{II})$ and $\mathrm{Hg}$ (II) with acetoacetanilude and isoquioline, Indian .J.Chem. 26 (Sect. A): 173.

12. Nakamato, N. 1997. Infrared Spectra of Inorganic and Coordination Compounds. Wiley Intrescience. Ed.6th.Newyork

13..Silvertisties, R.M., Bassler, G.C. and Morril, T.C. 1981. Spectrophotometer Identification of Organic Compounds, John Wiley and Sons, 4th. Ed.

14 .Lever, A.V. 1986. Inorganic Electronic Spectroscopy.3ed. Elsevier, New Yourk.

15. Figgie, B.N. 1966. Introduction to Ligand Field Interscience, JohonWiely and Sons, New York, London,.

16. Bailer,J.H., Emelens , H.J. and Nypholm,R. 1973. Comprehensive Inorganic Chemistry.Perganmon Press,Elsevier ,2ed.(5) ., New Yourk.

17. Carlin, R.T. 1965. Transition Metal Chemistry,1ed , Marcel Dekker Inc, New Yourk.
18. Jorgenson, C.K. 1962.Absorption Spectra and Chemical Bonding in Complexes. Addison-Wesley publishing company, England.

19. Osowole, A.A. 2008.Syntheses and Characterization of Some Tetradentate Schiff -Base Complexes and Their Heteroleptic Analogues ,J.G. of chemistry .5(1): 130-135.

20. Ahmed, A.A., BenGuzzi, S.A., Elhadi, A.A. 2007.Synthesis and Characterization of Divalent Transition Metals Complexes of Schiff Bases derived from OPhenylenediamine and Benzoylacetone and Related Species, J. of Science and its Application.11 (1): 79.

21. Elzahany, E.A., Hegab, K.H. and Safaa, S.K. 2008. Synthesis and Characterization and Biological of Some Transition Metal Complexes with Schiff Bases Derived from 2Formylindole, Salicyladehyed, and N-amino Rhodanin, Australian Journal of Basic and Applied sciences.2 (2):210 -220.

22. Tumer, M., Ekinci, D., Tumer, F. and Bulut, A. 2007. Synthesis, Characterization and properties of some divalent metal (II) complexes: their electrochemicale, catalytic, thermal and antimicrobial activity studies, Spectrochimical Acta Part A. 7(3-4):916-929. 


\section{تحضير , تشخيص ودراسة الفعالية البايولوجية لبعض معقدات -4-فلورو فنيل -4- نايتروينزلاين}

رفاه خالد /حمد **

أمبرة حسن حمد***

جيان عبد الله عليّث

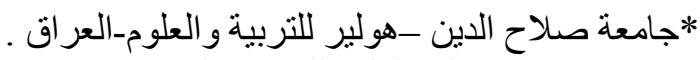

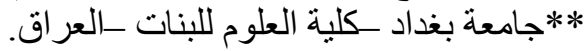

الخلاصة

تم تحضير قاعدة شف الجديدة 4-نايترو بنزلاين -4ـ فلورو انلين واستخدم هذا الليكاند مـع أيونات عناصر ثلاثلاثيـة

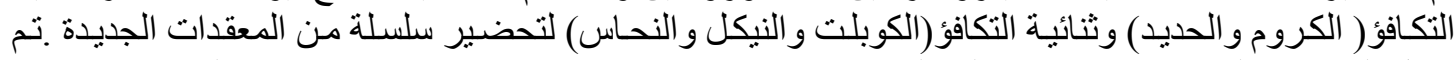

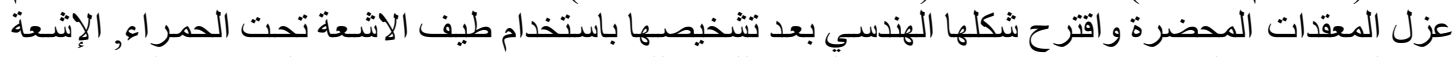

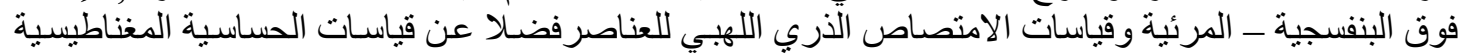

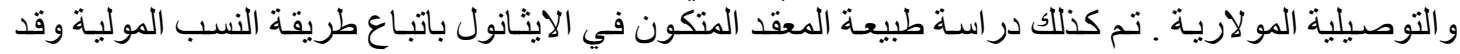

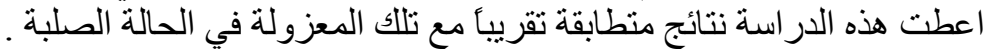

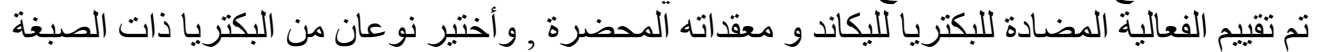

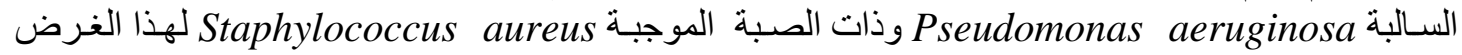

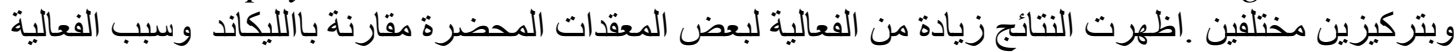
هو حصول التأثير التأزري بين الفلز و الليكاند فضلا عن الاختلانلاف في تركيب المركبات . 